\title{
INEZ OKULSKA
}

\section{Z „pomiędzy” Heaneya - Jarniewicz}

Jerzy Jarniewicz rokrocznie pojawia się na rynku wydawniczym: jako poeta, thumacz, literaturoznawca lub translatolog. W tym roku postanowił we wszystkie te role wcielić się na stronach jednej książki. Owocem takiej performatywnej ekwilibrystyki jest zbiór esejów o twórczości irlandzkiego noblisty pt. Heaney. Wiersze pod dotyk.

Interpretowanie czy recenzowanie książki będącej zestawem interpretacji (więc i na swój sposób recenzji) przysparza pewnych metodologicznych kłopotów, bo nasuwa na myśl platońską mimesis. Nie zajmę się więc tutaj tym, co o Seamusie Heaneyu pisze Jarniewicz (w tym celu zachęcam po prostu do lektury Wierszy pod dotyk), lecz tym, jak konstruuje narrację i czy tytułowy Heaney jest głównym tematem tej książki, czy może raczej pretekstem dla interpretatora do wypowiedzenia się także $\mathrm{w}$ innych kwestiach. A więc tym, co wyrasta pomiędzy elementami tekstu odnoszącymi się do życia i twórczości irlandzkiego noblisty. Nie bez kozery używam takiej przestrzennej metaforyki, ponieważ to właśnie ona $\mathrm{w}$ inicjalnych akapitach książki charakteryzuje poezję Heaneya. We wstępie Jarniewicz, nawiązując do wersu „wyrastałem pomiędzy”, pochodzącego z jednego z autobiograficznych wierszy Irlandczyka, efektownie retorycznie ustawia coś, co sam nazywa „szczególną kondycją Heaneyowskiego wiersza”. Zasadza się ona na pluralizmie języków, doświadczeń, wrażeń, przestrzeni i tożsamości, z których wszystkie są równoważne i nie pozwalają jednoznacznie dominować żadnej z nich. Pozostaje więc w wierszach Heaneya swoiste niedookreślenie, zawieszenie, „nieusuwalna różnica, jaką zapewnia im istnienie »pomiędzy «" (s. 7) ${ }^{\mathrm{x}}$.

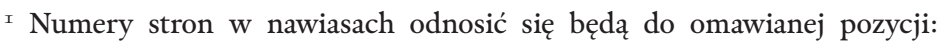
J. Jarniewicz, Heaney. Wiersze pod dotyk, Kraków 2011. 
Nie jest to tylko chwyt czy interpretatorska kokieteria, lecz konsekwentnie w całej książce realizowany pomysł na klucz do odczytań wielowarstwowej i wielowymiarowej poezji noblisty. Dzięki poszukiwaniom elementów „pomiędzy” poza zbliżeniem do tekstów wierszy (a stworzyła się w książce niemała ich antologia) czy esejów Heaneya, w dostępnych przekładach Piotra Sommera, Stanisława Barańczaka i Magdy Heydel lub własnych, zrobionych na potrzeby tej książki, Jarniewicz proponuje czytelnikowi także fascynujące podróże w głąb Irlandii, jej historii, kultury, polityki czy sztuki, przerzuca mosty paralel i analogii pomiędzy innymi poetami anglojęzycznymi, ciekawie rozrysowując mapę wzajemnych wpływów, przytacza kulturowe lub artystyczne zjawiska intencjonalnie niezwiązane z osobą czy twórczością Heaneya, ale trafnie ilustrujące opisywane przez autora Odpieśni do skowytu mechanizmy interpretacyjne. Ta szczególna lokalizacja - „pomiędzy” - odnosi się również do metodologicznego usytuowania Jarniewicza jako interpretatora. W badaniach nad twórczością Heaneya, w wielopiętrowych omówieniach łączy on bowiem w sposób przekonujący i wiarygodny myśl poststrukturalistyczną, dekonstruując teksty, sięgając po narzędzia pseudoetymologii, pozwalając sobie na bardzo odległe asocjacje, niemal puszczając wodze czytelniczej wyobraźni, jednocześnie nie rezygnując przy tym $\mathrm{z}$ tradycyjnych mechanizmów interpretacji ufundowanych na sumiennej pracy archiwistyczno-biograficznej. Dzięki temu badacz jawi się zarówno jako kreatywny erudyta, jak i jako prawdziwy znawca przedmiotu: w skali mikro (szczegółowa biografia i twórczość Heaneya) i makro (historia i związana z nią problematyka Irlandii).

Książka Wiersze pod dotyk to już drugi (choć nie wtórny) wynik drobiazgowych studiów Jarniewicza nad Heaneyem. Polski zbiór esejów o irlandzkim nobliście nie jest jednak przekładem książki The Bottomless Centre. The Uses of History in the Poetry of Seamus Heaney, choć pokrywa się w nich wiele fragmentów, tropów i odczytań. „Książka Jerzego Jarniewicza wyrasta z jednej strony z jego wieloletniej, intelektualnej i osobistej obecności pośród poetów angielskojęzycznych, $\mathrm{z}$ drugiej zaś $\mathrm{z}$ fascynacji zagadnieniem historii i sposobami w jaki kształtuje ona nasze publiczne i prywatne losy" ${ }^{2}$ - tak o habilitacji autora Odstuchiwania

2 T. Sławek, Dantejska bistoria Irlandczyków, „Literatura na Świecie” 2003, nr 11/12, s. 439. 
Larkina pisał Tadeusz Sławek. Choć historia nadal rysuje bodaj najważniejszy kontekst interpretacyjny i wciąż ze świecą szukać filozoficznych odniesień ${ }^{3}$, styl opisu uległ znacznej i znaczącej zmianie. Po trosze jest to z pewnością uwarunkowane wyswobodzeniem się z pęt formalnych zasad, jakimi rządzi się publikacja potwierdzająca stopień naukowy; związany z tym pisarski etos ustępuje tu miejsca swobodniejszej kompozycji retorycznych chwytów (wystarczy choćby prześledzić aforystyczne tytuły rozdziałów i ich śródtytuły, w angielskiej wersji raczej po prostu komunikatywne i rzeczowe). Co istotniejsze jednak, zmiana języka stała się również zmianą w języku. O ile w anglojęzycznym dyskursie literaturoznawczym Jarniewicz jawi się jako ceniony znawca, wnikliwy badacz, akademik, o tyle w polszczyźnie jest on także, a może przede wszystkim - poetą. Język opisu badanego materiału w naturalny sposób traci na przezroczystości, tworząc równoległy do niesionej treści, niemal autonomiczny estetyczny majstersztyk. Interpretacje poezji stają się tu na wskroś poetyckie. Dopiero polszczyzna daje Jarniewiczowi możliwości wypowiedzenia się w pełni: lekką, dowcipną, barwną, niemal rytmiczną frazą, która w pełni wykorzystuje gramatyczno-leksykalny potencjał ojczystego języka. Opisy tych samych rozpoznań w wierszach Heaneya stały się dłuższe (wystarczy porównać objętość obu książek), barwniejsze w skojarzenia, bogatsze we frazeologię, dźwięczne i malownicze, retoryczne (dużą frekwencją cieszy się na przykład klasyczna „trójka”), pojawiły się także dodatkowe językowe konotacje zakorzenione w polskiej kulturze czy języku, a więc przeznaczone dla polskiego czytelnika. Na przykład poetycko interpretując kulinarną sytuację w Ostrygach, Jarniewicz daje się omamić śpiewom polskich syren, rozpisując się na temat niebiańskości etymologicznie ukrytej w zmysłowych rozkoszach podniebienia - oryginalne angielskie palate takich asocjacji oczywiście nie umożliwia.

Z kolei rozdział czwarty (Pepek, pompa $i$ bombowce) merytorycznie odpowiada pierwszemu rozdziałowi habilitacji The Omphalos and the World Tree - znajdziemy w nim niemal identyczne fragmenty. Niemal - ze względu na tę jakościową różnicę w języku właśnie. Już pierwszy akapit - po angielsku transparentnym językiem wprowadzający $\mathrm{w}$ tematykę, w polszczyźnie otwiera silna inicjalna konstatacja „Pępek - nieco wstydliwy ślad, żeśmy z innego człowieka", po której następuje nawiązanie

3 T. Sławek zwracał uwagę na pewien niedostatek wątków filozoficznych w habilitacyjnej książce Jarniewicza, wskazując szczególnie na dojmującą nieobecność Nietzschego. Najwyraźniej świadoma taktyka rezygnacji z meandrów tropów filozoficznych kontynuowana jest w Wierszach pod dotyk. 
do ginealogii Moniki Zielińskiej. Takich amplifikacji w całym tekście spotkać można wiele. Oto przykład na poetyzację języka podczas swoistego autoprzekładu fragmentów zadawałoby się równoległych:

Analogicznie do nazwy Anahorish, która składa się z „łąki samogłosek” oraz Broagh, która zawiera „w dołku po twoim obcasie [...] ciemne o", samo brzmienie słowa „omfalos” przypomina poecie przedmiot, który to słowo oznacza. Sposób, w jaki poeta je wymawia, repetycja pierwszej sylaby, zmienia ją w rodzaj świętej mantry, pobrzmiewając echem odległej buddyjskiej inkantacji życiodajnego „om”.

To właśnie brzmienie powtarzanego słowa, jego całkowicie fizyczne cechy, przenoszą poetę z powrotem do czasów dzieciństwa, sielskiej wsi oraz rzeczywistego materialnego omfalosa: pompy. Słowo „omfalos" ewokuje na nowo przywołany obraz pompy z podwórka poety: pompy, która tam rzeczywiście stała ${ }^{4}$.

W książce Wiersze pod dotyk te same informacje zyskują nową, bogatszą retorycznie oprawę:

W podobny sposób, jak słowo Anaborish zawiera w sobie „łagodny stok spółgłoski” i „łąkę samogłosek” (przeł. S. Barańczak), a Broagh - ciemne $o$, „dołek po twoim obcasie” (przeł. P. Sommer), sam dźwięk słowa „omfalos” przypomina poecie przedmiot, który to słowo oznacza - ba, to słowo zlewa się ze swoim przedmiotem, staje się dźwiękiem pompowanej wody. W Heaneyowiskim trzykrotnym powtórzeniu pierwsza sylaba tego greckiego terminu odzywa się echem życiodajnej buddyjskiej sylaby om, zamieniając się mimo woli w mistyczną mantrę. [...] Greckie słowo kilkakrotnie rytualnie powtórzone rozbrzmiewa muzyką świętego zaklęcia z innego kręgu kulturowego, a jednocześnie oddaje najprostszą, najbardziej zrozumiałą mowę podwórka - odgłos pompowanej wody. „Omfalos” brzmi więc zarazem mistycznie i prowokująco prostacko: przywodzi na myśl świętą sylabę om i pospolitą pompę (s. 94)5.

4 „In a similar way to the name of Anahorish, which consists of a vowelmeadow, and Broagh, which includes »your heelmark [in] the black $\mathrm{O}$, «, the very sound of the word 'omphalos' reminds the poet of the object it denotes. In the poet's pronunciation, the repetition of the first syllable of the word changes it into a kind of a sacred mantra, echoing distantly with the Buddhist chant of the life-giving syllable - 'om'.

It is the sound of the repeated word, its very physicality, that takes the poet back in time to his childhood, to his rural Eden, and to the real, concrete omphalos: a pump. The word 'omphalos' evokes the recollected image of a pump outside the poet's back door: the pump stood". J. Jarniewicz, The bottomless centre. The uses of history in the poetry of Seamus Heaney, Łódź 2002, s. 17. Tłumaczenie - I. Okulska.

$5 \mathrm{~W}$ miejsce kropek w kwadratowym nawiasie autor wstawił dodatkowy akapit będący swoistą próbą usprawiedliwienia tak dalekich skojarzeń - 
Ta pompa, której formalna koincydencja współbrzmi z opisywanym terminem (mistyczna sylaba om), pojawia się w interpretacji i jako taka zostanie w pamięci czytelnika, mimo iż w przekładzie Sommera (o czym lojalnie informuje przypis) była ona studnią. Ten niewinny drobiazg, przypadek, w którym na potrzeby przybliżenia danego kontekstu czy zawartych w materii słowa oryginału sensów Jarniewicz przytacza własne przekłady, zawiesza lub thumaczy istniejące, nasuwa pytanie o recepcyjną konsekwencję takich autorytarnych gestów. We wstępie do polskiej monografii pojawia się refleksja na temat silnego poety: „Wiersz Heaneya, powstały i istniejący » pomiędzy «, mimo pozorów stabilności umyka absolutystycznej władzy interpretatorów, do nikogo w pełni nie należy, nikomu w pełni nie daje się zawłaszczyć" (s. 7). Czyżby? Lektura Jarniewicza sprawi, że nie będzie polskiego Heaneya Barańczaka czy Sommera, ale Heaney Jarniewicza, zawłaszczony przezeń dzięki tak obszernym, wnikliwym interpretacjom, nienachalnym, a jednak sprytnie niepodważalnym, bo niesamowicie silnie ufundowanym na rzetelnych badaniach historycznych, literackich, socjologicznych i lingwistycznych oraz rozległej erudycji autora. Po przeczytaniu Wierszy pod dotyk, obcując na przykład z utworem Wolne miejsca w przekładzie Barańczaka czy z Człowiekiem z Tollund Sommera, zawsze już będziemy mieli świadomość, że „pluskające słowem" kartofle to translatorski naddatek, a "nagi” jest nie tylko wykopany z bagien człowiek, ale także podmiot wiersza - dialektyka opisu, unicestwiona w przekładzie koniecznością polskiej fleksji. Interpretacje Jarniewicza, w których możliwe jest to, co w tłumaczeniu z konieczności musi ulec redukcji, które mogą dopowiedzieć i porównać równoległe teksty, legitymizują oba przekłady - jak w przypadku wiersza Kara, który dopiero $\mathrm{w}$ translatorskim dwugłosie (a więc dzięki zestawieniu ich przez Jarniewicza) oddaje pełnię metaforyki Heaneya (i erotyczną, i religijną) (s. 134). I może to jest jakaś odpowiedź na wyrażoną na łamach „Literatury na Świecie” sugestię Jeana Warda, jakoby „polski Heaney”, mimo istniejących tłumaczeń, okazywał się bytem niekompletnym ${ }^{6}$. Może ten rozległy, wnikliwy interpretacyjny element będzie satysfakcjonującą substytucją (protezą, dopełnieniem?) brakujących lub niemożliwych przekładów?

co ciekawe: poprzez przeniesienie „odpowiedzialności” na samego Heaneya, sugerując, że zgrabne łączenie w jego poezji odległych biegunów uzasadnia zuchwałe interpretacje jego wierszy czy pojawiających się w nich kategorii.

"Por. J. Ward, Kilka „angielskich” uwag na temat polskiego obrazu poezji Seamus Heaneya, „Literatura na Świecie” 1998, nr 7/8, s. 448. 
Bardziej poetycki język i przeniesienie punktu ciężkości z toposu historii na historycznie zakotwiczone interpretacje poszczególnych wierszy czy wątków - to nie jedyna różnica jakościowa między anglojęzyczną habilitacją a polską monografią. Choć jest ona zbiorem autonomicznych artykułów, daje się spokojnie czytać jak powieść, od deski do deski (z klasyczną kompozycją opartą na punkcie kulminacyjnym!). I skoro rozpatruję ją w kategorii tekstu literackiego, a nie tylko literaturoznawczego, chciałabym wyróżnić trzy typy narracji, które się w niej pojawiają; głos Jarniewicza nie jest tu bowiem fizyczną konsekwencją wypowiadania się o kimś w roli znawcy czy interpretatora, lecz śladem autonomicznej i, jak się okaże, nieco apodyktycznej obecności drugiego poety. Narracja pierwszoosobowa dzieli się na tę, w której autor przejmuje całkowitą odpowiedzialność za bardziej odważne sądy lub też nawiązuje do osobistych, jednostkowych doświadczeń - silne i świadome „ja” (np. „Świadomy jestem niebezpieczeństw związanych ze sprowadzeniem poezji do jej genetycznych uwarunkowan'”, s. 249) oraz podmiot zbiorowy, który służy Jarniewiczowi do przemycania pewnych koniecznych oczywistości lub po prostu prowadzenia narracji mniej inwazyjnej czy płynnego łączenia elementów wypowiedzi („Przypomnijmy”, „Powróćmy”, „Jak wiemy” itp.). Wreszcie trzecia forma to bezpodmiotowe konstruowanie definicji. Ten bezosobowy autorytarny ton obwieszcza ogólne prawdy dotyczące Heaneya (mówiąc, jak jest), ale w istocie tak skonstruowane, że jeśli wyabstrahować je z kontekstu zdań sąsiadujących, które wskazywałyby na to, że mowa jest o irlandzkim nobliście, można by je ułożyć $\mathrm{w}$ osobną antologię definicji i programowych założeń na temat instytucji poezji i poety lub krytyki literackiej. Świadomie używam frazy „programowe założenia”, ponieważ druga, bardzo ważna warstwa tej książki to osobisty manifest Jarniewicza, jego własny poetycki i krytycznoliteracki program, który można „pomiędzy” opowieścią o twórczości autora Kolejowych dzieci wyczytać7. Ten rodzaj palimpsestowej lektury będzie pewnie nieco przypominał Barthesowską mitologię: sformułowanie programu przez Jarniewicza jest bowiem nadbudowane na pierwotnym znaczącym (a więc interpretacjach twórczości Heaneya) poprzez nadanie mu nowego kontekstu.

7 Por. moje krótkie omówienie tej książki w czasopiśmie internetowym „Dwutygodnik” nr 52, gdzie wstępnie ten problem zasugerowałam. (http:// www.dwutygodnik.com/artykul/2115-jerzy-jarniewicz-heaney-wierszepod-dotyk.html, data dostępu: 27.9.2011). 
Formy pierwszoosobowe tej narracji implicite, poprzez dawanie przykładu godnego naśladowania, uczą, jak pisać o poezji. Studium interpretacji wiersza Heaneya zamienia się tu, jak już pisałam, w czystą poezję, idealnie balansuje na granicy mariażu niemożliwego: jednocześnie przytaczając rozległe konteksty historyczno-biograficzne i dekonstruując je. Przypominając tym samym czytelnikowi, że erudycja i fantazyjność asocjacji to jedno, ale rzetelne przygotowanie do lektury podparte wiedzą z zakresu historii, historii literatury, kultury danego kraju, polityki i równoległych mogących mieć wpływ trendów w innych sztukach - jest po prostu niezbędne. Jarniewicz w tym przypadku występuje nie tylko w roli podmiotu - jako bezinteresowny nauczyciel trudnej sztuki interpretacji - lecz także jako poeta, a więc przedmiot już zaistniałych i przyszłych omówień, i jako taki sugeruje ich techniki. Niezaprzeczalnie najbardziej efektowną interpretację zarówno pod względem retorycznym i konceptualnym, jak i dzięki rozległym objaśnieniom historycznym i kulturowym, otrzymujemy w rozdziale zatytułowanym „Przekleństwo przywileju", gdzie brawurowej analizie poddany zostaje wiersz Ostrygi. Tam też kryje się jedno z owych „programowych założeń", zachęcające do lektury wielowymiarowej: „Wiersz ze swojej natury rozwija się linearnie, wers za wersem, ale w każdym niemal obrazie wydaje się otwierać pod stopami jak trzęsawisko, przejmując czytelnika i wiodąc nie dalej, a w głąb podziemie słów, obrazów, zdań” (s. 200).

Narracja oparta na bezosobowych definicjach w sposób eksplicytny konstruuje też model poety i poezji. Jakie są sformułowane założenia programowe Jarniewicza-poety? ${ }^{8} \mathrm{Na}$ pierwszy plan wysuwają się rozterki poety i badacza literatury, który wzrastał i doskonalił swój warsztat na przełomie strukturalizmu i myśli poststrukturalistycznych: dialektyka obu postaw, której walory autor dostrzega i docenia, próbując je na swój użytek łączyć (stąd ten „mariaż niemożliwego” w jego własnych odczytaniach). $\mathrm{Z}$ jednej strony, postuluje o przestrzeń dla interpretatora: „Wiersz, który cokolwiek czytelnikowi narzuca, nie jest wart lektury” (s. 201), czy zauważa, że „jeśli więź między słowem a przedmiotem zostaje zerwana, bo słowo za słowem, a nie za rzeczą bieży, to pytanie o prawdę, czyli o relację między nimi, traci sens" (s. 168). Z drugiej zaś - ustami Heaneya wyznaje, że „poeta marzy o poezji, w której ostrygi będą ostrygami, a nie znakami [...]” (s. 215) lub też z przekąsem (i autoironią?) kon-

8 Świadomie pytam tu wyłącznie o sformułowane założenia programowe. Zestawienie ich z poetyką rzeczywiście realizowaną wymagałoby osobnej rozprawy. 
statuje, że: „z poszukiwania etymologii, która umotywowałaby sens słowa, niektórzy poeci i filozofowie uczynili podstawowy chwyt swojej sztuki” (s. 179).

Dwa ostatnie rozdziały książki - esej o Herbercie i Miłoszu - wyraźnie odstają od reszty, po pierwsze dlatego, że środek ciężkości narracji przeniesiony został $\mathrm{w}$ stronę polskich poetów, którzy zamiast budować kontekst, jak w przypadku fotografii ludzi z bagien, czy ciekawą paralelę, jak wystawa Libery, wybijają się na pierwszy plan i absorbują uwagę interpretatora, Heaneya czyniac nie do końca umotywowanym dodatkiem. W przypadku Herberta esej dotyczy porównania kamyków u obu poetów, mających zilustrować Herberta i Heaneya idiomatyczne studium przedmiotu (u Herberta - reifikacja à rebours). W efekcie na pięć podrozdziałów cztery zawłaszcza Herbert, by dopiero w ostatnim na chwilę $\mathrm{i}, \mathrm{w}$ porównaniu $\mathrm{z}$ pozostałymi esejami, nieco bez polotu, pojawił się Irlandczyk. Przyjęta perspektywa i proces interpretacji $\mathrm{w}$ obu przypadkach wydają się nieco naciągane, a opis Herbertowskiej reifikacji to poprawny, lecz pozbawiony tego niesamowitego poetyckiego waloru pozostałych esejów montaż opinii i cytatów z powszechnego zbioru „należy wspomnieć". Intuicja podpowiada, że tylko dalekie powinowactwo tematyczne pozwoliło wejść temu tekstowi do książki - i słusznie, pierwotnie ukazał się on bowiem w numerze czasopisma „Odra” (2009 nr 1)9 , w bloku szkiców poświęconych Herbertowi, a nie Heaneyowi. Co ciekawe (i może warte osobnej interpretacji), nawiązujące właśnie do tego eseju „kamyki” pojawiają się na okładce książki Jarniewicza.

To swoiste rozczarowanie czytelnik projektuje również na esej o Miłoszu, w którym znów do głosu dochodzą: fascynacja historią, nadmiar wątków biograficznych i wypowiedzi obu poetów oraz sytuacji ich realnego spotkania. Oba rozdziały sprawiają wrażenie jakby doklejonych - rozszczepiają wcześniejszy spójny koncept. Wobec uprzednio wysoko ustawionej poprzeczki zdają się być „po prostu” rzetelnymi omówieniami, bez wcześniejszego potencjału poetyckiego (a wręcz zdarzają się zabawne konstrukcje językowe, jak: „wiersz w pierwszym wersie ożywia kamyk, żeby go w drugim tego życia pozbawić doskonałością”

9 Wcześniejsza wersja tego rozdziału znalazła się w tomie Herbert (nie)oswojony, red. W. Browarny, J. Orska, A. Poprawa, Wrocław 2008. 
czy „pleonastyczna przydawka »kamienny « rezonuje mrowiem znaczeń”), do tego jednowymiarowe. A jednak poruszone zostają tu dwie kwestie (oczywiście nie wprost, a znów „pomiędzy”), dla całości Wierszy pod dotyk niemal kluczowe: palimpsestowy charakter pomieszczonych w książce esejów oraz stosunek Jarniewicza-poety do Heaneya. Oba fragmenty, choć odnoszą się do poezji Herberta lub postawy Heaneya (komentarz do wypowiedzi o jego związkach z Miłoszem), z powodzeniem odczytać można jako autonarrację Jarniewicza. A więc znów z „pomiędzy” autor Skadinad przemawia głosem poety, tym razem jednak nie manifestuje już ogólnego poetycko-krytycznego programu, lecz przemyca drogowskazy dla czytelnika, by ten nie dał się wyprowadzić na manowce literalnych odczytań:

Autorytarnie brzmiące tezy należy prześwietlić; oczywistość wersów, jaka ma niby wynikać z języka doprowadzonego na skraj prostoty, uznać za daleką od oczywistości (s. 234).

I dalej, w rozdziale zatytułowanym „Momenty wieczne Heaneya i Miłosza":

[Spotkanie Heaneya z Miłoszem, ale równie dobrze Jarniewicza z Heaneyem - I.O.] wiązało się dla Heaneya [Jarniewicza] z odkryciem nowego „starego mistrza”, któremu mógł przypisać swoje wieszcze, etyczne i mądrościowe - rozumienie roli poety i poezji; dostatecznie dalekiego, pokoleniowo, kulturowo i językowo, by nie bać się, że zawładnie dykcją czy wyobraźnią młodszego kolegi, a jednocześnie na tyle monumentalnego, że rodził poczucie szacunku połączonego $\mathrm{z}$ trwogą i świadomość obcowania $\mathrm{z}$ wielkością, a poza tym wszystkim wyznaczał pewien niedosięgły już dziś, a może wręcz anachroniczny wzorzec (s. 273).

To także swoista próba osłabienia apodyktyczności wyrazu oraz odżegnania się od zbyt bliskiej intelektualnej więzi z poetą, którego tak wnikliwie studia mogłyby odcisnąć literackie piętno na badaczu. W swoistym apendyksie pojawia się więc z ducha postmodernistyczny gest podcięcia postawy, którą wyczytać mogliśmy we wcześniejszych dziewięciu rozdziałach, na ponad dwustu stronach książki. Ten gest antycypowany jest już zresztą w końcówce dziewiątego rozdziału, gdzie po kilkunastostronicowej interpretacji wspomnianych Ostryg, tak gęstej, wnikliwej i po prostu absolutnej, niepozostawiającej już przestrzeni na dodatkowe komentarze, tropy czy odczytania, pojawia się zabawna konstatacja dotycząca finalnych wersów: „Niejednoznaczna to koda niejednoznacznego wiersza” (s. 216). 
Ów początkowy przyimek, to nieustannie przejawiające się „pomiędzy", które ukonstytuowało nie tylko poezję Heaneya, lecz również poświęconą jej książkę Jarniewicza, staje się największą zaletą obu autorów. Afirmatywny stosunek względem takiej proweniencji twórczości irlandzkiego poety można bowiem odnieść również do omawianej tu pozycji. Parafrazując cytat ze wstępu: jeśli książka Heaney. Wiersze pod dotyk „,warta jest grzechu wielokrotnie ponawianej lektury, a nie mam wątpliwości, że jest, to przede wszystkim dlatego, że przychodzi do nas spomiędzy, a raczej z » pomiędzy «" (s. 5).

\section{INEZ OKULSKA}

\section{From “in between" by Heaney - Jarniewicz}

The subject for the critical and literary comments in the present article is, in the first instance, the collection of essays devoted to the literary output of the Irish Nobel prize-winner Seamus Heaney written by Jerzy Jarniewicz and entitled "Wiersze pod dotyk". Though this is the chief reason, but not the only one, as this seemingly innocent monograph book turns out to be a gem in itself with regard to the poetical artistry of the Polish author of the essays. And so, the reader finds the following: poetical language of description, poetical sensitivity in reading and a particular poetical manifesto that has a programme-character for Jarniewicz-poet. And all this is revealed form the eponymous "in between", from between the verses, reading material, fascination and connotations of the author.

Key words: Seamus Heaney, Jerzy Jarniewicz, Irish poetry, literary review, poeticality of description, literary criticism.

Inez Okulska - doktorantka w ramach podwójnego programu Instytutu Filologii Polskiej UAM w Poznaniu oraz Translation Studies na Europejskim Uniwersytecie Viadrina we Frankfurcie nad Odrą, gdzie zajmuje się interdyscyplinarnymi badaniami nad teorią przekładu literackiego. Tłumaczka i krytyczka literacka, także literatury w przekładzie, redaktorka translatorskiego rocznika „OderÜbersetzen”, publikuje m.in. w „Literaturze na Świecie”, „Twórczości”, „Czasie Kultury”.

e-mail: inez.okulska@gmail.com 